\title{
Observations on Access and Use of Public Space during COVID-I 9 in Hong Kong and Taipei
}

\author{
Ying-Fen Chen, Yu Sze Cheung, Hendrik Tieben \\ The Chinese University of Hong Kong, School of Architecture, Hong Kong SAR \\ aei.aurora@gmail.com | syscheung@cuhk.edu.hk | hktieben@cuhk.edu.hk
}

\begin{abstract}
This paper compares the conditions and related responses during the COVID-I9 pandemic in Hong Kong and Taipei, two cities which were among the first to be affected by the pandemic after the virus was first discovered in Mainland China. The cases of both cities offer interesting observations due to their earlier experiences with the SARS epidemic, which led to their prompt reaction, and helped to avoid general lockdowns and to keep most public spaces open. Public space, in the later discussion of worldwide pandemic, has been recognized as a crucial urban facility to mediate people's outdoor activities and secure health and wellbeing issues. The more detailed comparison, however, identifies specific issues particularly in Hong Kong, where, despite the generally low number of infections and fatalities, the severe pre-existing socio-spatial inequalities were further exacerbated and affected vulnerable groups, such as domestic workers, elderly and urban poor. At this early stage, the paper aims to identify which policies have helped most, and which challenges would need to be addressed to improve people's health and wellbeing and prepare better for future crises, particularly in the aspect of public space. The study of these two highly urbanized and densely populated cities is also relevant for the current debate about the relationship between urban density and pandemics, as both cities demonstrate that through decisive actions and civic responsibility, infection numbers could be kept comparably low.
\end{abstract}

Keywords: Hong Kong, Taipei, public space, health and wellbeing, COVID-19 pandemic

To cite this article:

Chen, Y. F., Cheung, Y. S., Tieben, H. (2020). Observations on Access and Use of Public Space during COVID-19 in Hong Kong and Taipei, The Journal of Public Space, 5(3), 9I-I04, DOI I0.3289I/jps.v5i3.I38I

This article has been double blind peer reviewed and accepted for publication in The Journal of Public Space. 
COVID- 19 took the world by surprise in 2020, as of 20 July, there are over 14.34 million cases confirmed worldwide, with 603,69l deaths (World Health Organization, 2020). What also took the world by surprise is the low number of confirmed cases and deaths in Hong Kong ( 1,886 cases and 12 deaths) (Centre for Health Protection, 2020) and Taiwan (455 cases and 7 deaths) (Taiwan Centers for Disease Control, 2020a)', two places with close proximity and ties with Mainland China, where the first cases of COVID-19 were identified in late 2019. Both places swiftly contained the pandemic, flattened the curve and transmission rate. Many accounts the success to experiences and learnings from SARS, as both governments swiftly responded to the crisis with wellcoordinated mechanisms, leading to stringent travel and quarantine controls, extensive contract tracing and testing, physical distancing measures supported by a collaborative response by the civil society. Larger community outbreaks have been prevented so far, and thus, in contrast to many other places, both Hong Kong and Taipei did not go through a de facto lockdown. While school teaching went online in Hong Kong, in Taipei it was still conducted face-to-face, businesses were encouraged to allow workfrom-home practices, and citizens were recommended to wear masks in public spaces and keep appropriate physical distance, yet most restaurants and businesses remained open, and, in contrast to many other cities worldwide, access to public spaces was not drastically affected. This is even more remarkable considering the high urban density of both cities and the related difficulties for physical distancing.

This article, written during the ongoing pandemic, shares observations of the use of public space in these two cities, trying to pinpoint issues that have emerged. These issues reflect how the city's urban environment as well as specific policies affect the population's health. Although the two cities launched similar policies of epidemic control in the beginning, subsequent policies regarding public spaces-as specific locations with both the risk of community outbreak and the opportunity of keeping people physically and mentally healthy-were established based on the urban spatial differences and similarities in Hong Kong and Taipei (urban density, condition of public spaces, major urban issues, etc.). The comparison of these policies should be understood to further improve pandemic preparedness and overall well-being of the population.

\section{Developing Epidemic Prevention Strategies from the 2003 SARS Experience} Both Hong Kong and Taipei were seriously hit by the Severe Acute Respiratory Syndrome (SARS) in 2003, which also was first identified in Mainland China, causing a deep fear in the population of the disease. These experiences transformed the cities' public health systems, and more importantly, people's mindset and values. In Hong Kong, a new Infectious Disease Centre was built, and the Centre for Health Protection (CHP) was established under the Department of Health in 2004. Likewise, to develop a thorough prevention system, a novel governmental sector, the National Health Command Centre (NHCC) was established in Taipei in 2004 (Taiwan Centres for Disease Control, 2018). These two centres played an important role in the response to the COVID-19 pandemic by coordinating the efforts of academics, health practitioners

\footnotetext{
I Taiwan is considered by Mainland China and UN as a province of China, which statement is either debating or disagreeing in other contexts around the world.
} 
and the government, and hosting daily media conferences to report on the latest COVID-19 updates. In addition, microbiologists and scientists published important findings during and after SARS and became international key opinion leaders people listened to this time. The general public gained essential hygiene knowledge and acted readily as another pandemic hit Hong Kong and Taipei again after 17 years.

Such experiences meant prompt response in the current health crisis for both cities. The Hong Kong government's first step was to exercise tracking and quarantine control from the start of COVID-19. Preparedness and response plan was launched as early as 4 January 2020 when Hong Kong had no confirmed case yet. On the same day, "serious response level" was also launched, a steering committee was formed to coordinate response work. ${ }^{2}$ In Taipei, the government also leveled up in the beginning of January. The Centres for Disease Control and Prevention (CDC) under NHCC was in charge of coordinating prevention strategies and considered border control as a top priority (The Reporter, 2020). ${ }^{3}$ By 25 March, all non-Hong Kong residents were not allowed to enter Hong Kong, similar restrictions were implemented in Taipei.

On the community level, wearing masks was the first reaction of people in Hong Kong and Taipei, causing panic buying and mask shortages. To ensure citizens all have access to masks, CDC in Taipei established a series of mask policies as the first action of epidemic prevention. Since 24 January, export of medical masks was banned for one month and was extended afterwards. The government controlled the mask production lines and market by regulating prices and distribution approaches, assuring that hospitals and clinics could get enough masks for medical uses, while guaranteeing citizens a certain number of masks every week (Chen and Hau, 2020). As the National Health Insurance $(\mathrm{NHI})$ provides every citizen with a social insurance plan, every citizen has a complete medical record since 1995. Based on this system, the government could regulate the masks distribution and purchase. In addition to citizens registered with $\mathrm{NHI}$, the government designed various approaches for non-citizens such as migrant workers and other foreigners to enable them to buy masks (National Health Insurance Administration, 2020). ${ }^{4}$ These responses created trust in the government's handling of the crisis in Taipei (Zheng Wei, 2020) ${ }^{5}$. In addition to the government's policy of masks control, individual technicians created several online maps based on the mask storage

\footnotetext{
${ }^{2}$ On 25 January, a ban of direct flights and high-speed rail to and from Wuhan was issued, and to counter the second wave of infections, a ban was issued on 25 March and all non-Hong Kong residents coming from overseas countries or territories arriving at the airport were not allowed to enter the city, makeshift virus test centres were set up. Since then, home quarantine entries were tracked via the newly invented wristbands and mobile app. All close contacts of confirmed cases were tracked and sent to testing, and if necessary, quarantines.

${ }^{3}$ The government began requiring citizens arriving from Hubei Province submitting travel reports at the customs and beginning to track the people under quarantine by electronic monitoring system on 28 January. Later on 2 February, citizens from Mainland China were banned from entering; 8 February, all kinds of transportation to Mainland China were suspended; and ultimately on 18 March, all non-citizens were banned from entering Taiwan while citizens traveling back were required quarantine for 14 days.

${ }^{4}$ From 9th April onward, Citizens living overseas, were allowed to receive a certain number of masks from relatives in Taipei.

${ }^{5}$ The press launched an opinion poll about the people's satisfaction of the government's reaction to COVID-19 specifically in the aspect of mask policy, which showed that around 70\% residents were standing for this policy.
} 
estimating system published by the government to help people purchase masks from available pharmacies efficiently (Shiroma, 2020).

In Hong Kong, the situation at the arrival of the pandemic was different as the territory had just experienced over seven months of political unrest (Lam, Sum and Ng, 2019).

Before this political backdrop, parts of Hong Kong's population criticized the government for the lack in the provision of hygienic items such as masks and disinfectant hand wash in the first months of the crisis, as well as the strongly increased prices of these essential items. Even for medical staff, it had been difficult to get adequate protective items, so that their union had to pressure the government to increase supply (Rizzo and Hersher, 2020). After two infection waves had passed, on 5 May, the Hong Kong government announced that all residents could apply for free reusable CuMask+ ${ }^{\mathrm{TM}}$, a commissioned project initiated by the Innovation \& Technology Bureau. The masks were distributed to citizens by online registration, stormed concerns over privacy and queries over the effectiveness of the mask due to inconvenient and impractical procedures for cleaning (Ho, 2020; Zhang, 2020).

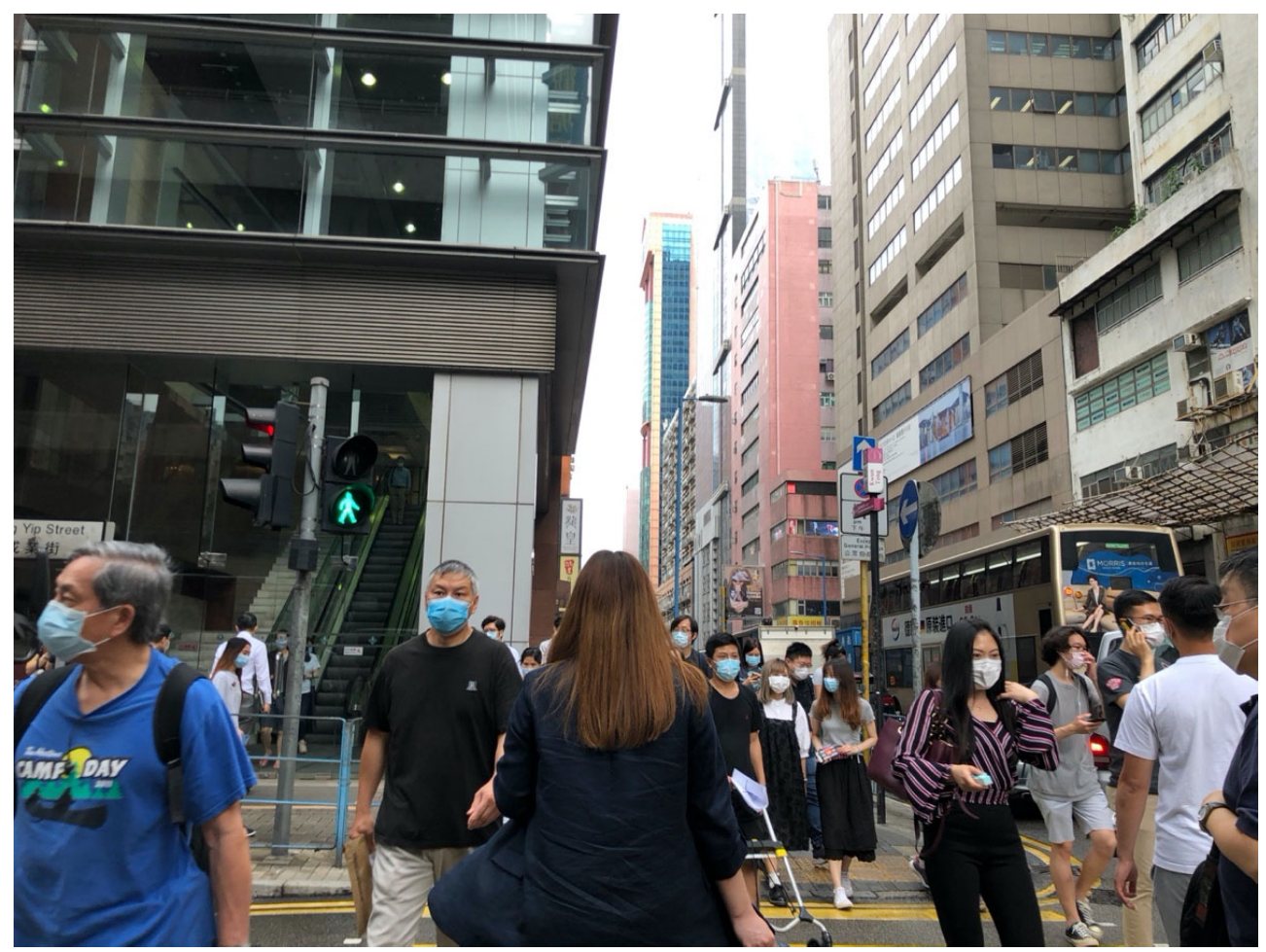

Figure I. Street crossing in Kwun Tong, Hong Kong (May 2020).

\section{Approaches on Regulating Large-Scale Activities and Physical Distancing}

Despite the above difficulties in provision of protective gear in the first months, the overall swift actions in both cities prevented (up to the point of writing) wider community outbreaks. Thus, Hong Kong and Taipei did not experience lockdown or shelter-in-place regulation as many other cities worldwide. In Taipei no large-scale bans or enforced closures of public or private commercial spaces were issued. The government suggested citizens to wear masks in hospitals and crowded indoor spaces, 
such as department stores, theatres, museums, campus buildings, during the first wave of infection (Taiwan Centres for Disease Control, 2020b). Also, the highly frequented mass-transit systems in both cities remained open. After the second wave hit Taipei in mid-March, with the return of overseas citizens from more affected areas, citizens were required to wear masks on public transportation and most indoor public spaces (Strong, 2020). After the second wave of infections in Hong Kong in late March, more stringent physical distancing restrictions were imposed to reduce the chance of larger community outbreaks ${ }^{6}$. The Hong Kong government also announced the closure of bars, beauty parlours, clubhouses, nightclubs, as well as premises for karaoke, mahjong tin-kau and massage, and premises selling liquor. In addition, it imposed a ban for gatherings with more than four people in public spaces. Public facilities such as libraries, study rooms, museums, playgrounds, sports centres, and alike in Hong Kong were closed for most of the time, while public services such as child-care centres and day-care centres for elderly were also affected. These bans and closures have gradually been lifted and relaxed since 9 May. Due to a third wave of infections in Mid-July, tighter restrictions were implemented again, in addition to all types of premises' closure, and for two days restaurants had to cease dine-in services. Also, a mandatory mask-wearing policy was imposed in all public indoor and outdoor spaces, and group gatherings were limited to two persons.

Citizens in Hong Kong and Taipei largely complied with physical distancing measures implemented and suggested by the governments. Over $95 \%$ of Hongkongers wore masks (Zheng, 2020), avoided social gatherings and meetings, worked from home, and stayed at home even before the compulsory physical distancing rules kicked in. Essential practices such as washing hands, washrooms hygiene, improving toilet pipes all helped, according to Dr Ho Pak-Leung, Head of University of Hong Kong's Centre for Infection. The discussions of physical distancing and lock-down also emerged in the organization of large-scale religious activities which traditionally are celebrated in the first months of the year. Outside of Taipei, many traditional festivals were affected, such as the Mazu Festival and Pilgrimage. During the rituals, devotees traditionally gather and follow the gods in a large parade, some of these rituals have become large-scale festivals attracting believers and tourists. In February, due to the fear of COVID-19, the organization of these festivals became the centre of debates in the news and social media. Some temple managers considered the high amount of already-made expenses and expected the rituals would potentially bring power over the virus. However, the public believed that cancelling this year's festivals would be the only way to avoid a community outbreak. Eventually, the government abstained from emergency orders to cancel the festivals, but temple managers ultimately took the advice from the CDC and cancelled the event under public pressure. Meanwhile in Hong Kong, all large-scale events and religious activities were cancelled to comply with the government's physical distancing measures.

\footnotetext{
${ }^{6}$ Made by the Chief Executive in Council under section 8 of the Prevention and Control of Disease Ordinance (Cap.599) (Or Cap. 599).

${ }^{7}$ Premises include amusement game centres, bathhouses, fitness centres, places of amusement, places of public entertainment, party rooms, clubs or nightclubs, karaoke establishments, mahjong-tin kau premises, beauty parlours, massage establishments, sports premises and swimming pools.
} 
These examples present the key aspect of the success in both cities: The governments imposed responsive and stringent regulations, while informed residents followed widely the regulations as they appealed to their own sense of civic responsibility (Shan, 2020).

\section{People's Use of Public Space under the Pandemic}

While these measures in both cities could be seen as an overall success, certain challenges are observed below and will be further studied in follow-up papers to improve preparedness for future pandemics. These challenges are linked to three factors: (I) the general lack of sufficient and appropriate public and private space, particularly in view of the extreme urban density of Hong Kong; (2) the social polarization and health disparity exacerbated by the pandemic; and (3) the insufficient and uneven access to health provisions (e.g. health insurances, testing, and masks) as well as access to internet.

Both cities are very densely populated: with Hong Kong having an average density of 6,940 people per sq. $\mathrm{km}$, with the densest district reaching 61,560 people per sq. $\mathrm{km}$ in 2019 (Census and Statistics Department HKSAR, 2020); while Taipei has an overall density of 9,918 people per sq. $\mathrm{km}$, the most densely populated district reached 27,418 people per sq. km in 2016 (Taipei City Government, 2017). Residents in Taipei enjoy 5.7 sq. $\mathrm{m}$ of open space (including green space) per person in 2018 (Public Works Department Taipei City Government, 2019). Hong Kong's Planning Department Guideline requires 2 sq. $\mathrm{m}$ of open space per person, in the poorer and highly dense districts the open space amount per person is much lower in reality (Chow, 20I8), a stark contrast with the standard of World Health Organization at 9 sq. $\mathrm{m}$ per person. According to a recent report, open space in Hong Kong is also highly unequally distributed (Lai, 2017). This is particularly critical in Hong Kong as average living space per person is only 170 sq. $\mathrm{ft}(\sim 15.8$ sq. $\mathrm{m})(\mathrm{Ng}, 20 \mathrm{I})$, even worse, 209,700 people live in subdivided units with a median living space of $57 \mathrm{sq} . \mathrm{ft}(\sim 5.3 \mathrm{sq} . \mathrm{m})$ per person (Census and Statistics Department HKSAR, 2018).

These crammed living conditions made neighbourhood public spaces essential breathing spaces before COVID-19, and even more so during the pandemic when many other public facilities and school premises were closed. Even though these public spaces are not ideal, people needed them to exercise and get fresh air especially during the pandemic. Yet, the distribution of public spaces in the dense urban areas in Hong Kong is mostly scattered and individual spaces can only be reached via crowded streets with narrow sidewalks. The implementation of mandatory mask-wearing in public space further exacerbated the issue of accessibility. Particularly in the poor neighbourhoods in early days of the outbreak, residents could not afford masks and sanitizers as the prices spiked up. Hong Kong's large country parks and greeneries, which take up three quarters of the territory, became a significant refuge with parts of the population flocking to these green spaces during weekends and public holidays. However, vulnerable groups might not be able to reach these country parks because of various difficulties, such as long working hours, expensive transportation costs, lack of information, physical disabilities, etc.

In Taipei, planning initiatives had started to create and connect large public space networks along the waterfronts as well as within the urban areas; and streets in older districts often have no separations between pedestrians and cars, allowing people to extend their activities into the car-lanes if needed. Large investments into a continuous 
system of riverside parks created a large public space infrastructure, which include wetland areas with bicycle lanes and spaces for a high diversity of outdoor sports and activities. These riverside areas were separated from the urban space by dikes to prevent Taipei from flood disaster before the 1980s. However, as traditional ideas of flood prevention changed, these spaces between the city and the river were redesigned to public parks during normal days and retarding basins during typhoon season (Yau, 200I). As community outbreaks were avoided and masks made available for all income groups, this system that supposed to create the city's resilience to flood disaster was heavily used during the pandemic and provided alternative transport-options and spaces for physical exercise and mental relief. Moreover, to develop a sustainable and green urban environment as well as reinforcing residents' physical and mental health, Taipei City Government established a bicycle-sharing system "YouBike" in 2012 (YouBike Co., 2020). From January to March 2020, the bikes were borrowed 200,000 times more than the same period in 2019, with a significant decrease of people taking public transportation like buses and MRT as they were considered high-risk spaces for virus transmission (Tsai, 2020).

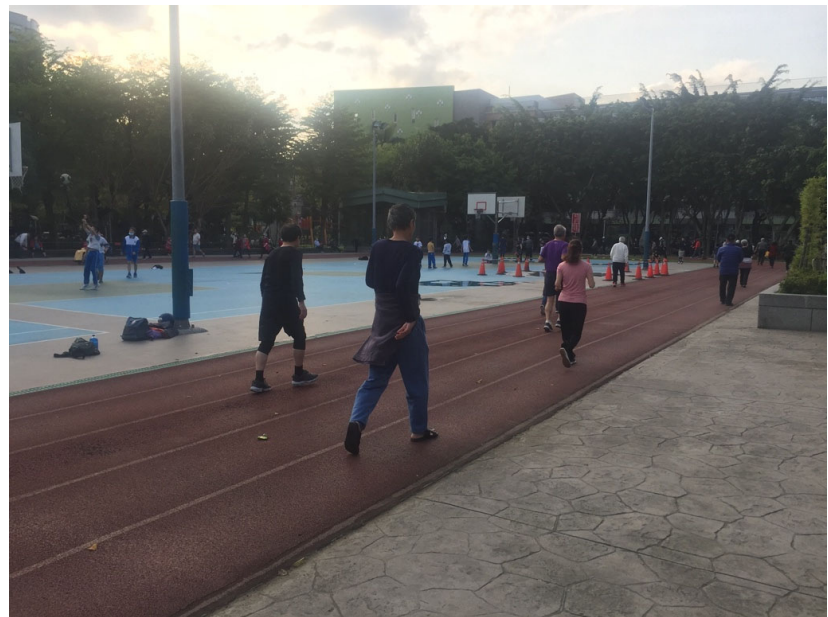

Figure 2. Most of Taipei's public spaces remained open throughout the pandemic for residents to exercise and relax (photo April 2020).

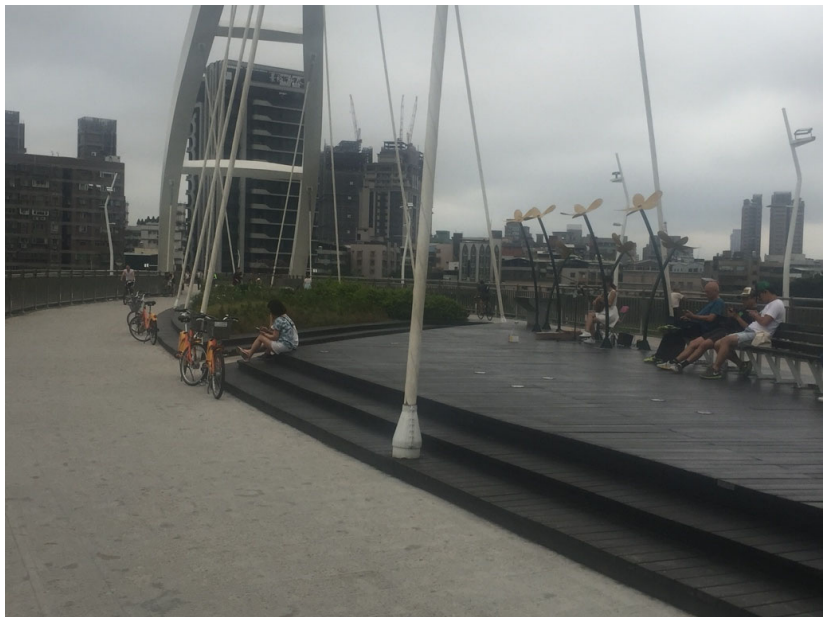

Figure 3. The bike lanes and share bike system in Taipei became even more popular during the pandemic. New public spaces such as pedestrian and cycle bridges became favourite places for people to rest (photo May 2020).

The Google Mobility Report also shed light on and confirmed observations on how citizens responded to physical distancing guidelines and alluded to remarkable differences between the two cities. Hong Kong citizens' movement significantly dropped (35\% in retail \& recreation, $37 \%$ in public transport, $30 \%$ in workplace, and $26 \%$ in parks), and a 19\% increase in residential areas (Google, 2020a), whereas in Taiwan ${ }^{8}$ there actually was a $6 \%$ increase in the movements to parks, and only a slight drop of $2 \%$ in retail \& recreation (Google, 2020b) (as of 21 July 2020). Except preventive steps like testing body temperature, cleaning hands with $75 \%$ methanol, and wearing masks as suggested by the government and initiated by citizens before getting into indoor (semi-

\footnotetext{
${ }^{8}$ See the first footnote for more clarification.
} 
)public spaces like restaurants, stores, museums, movie theatres, governmental buildings, people's behaviours in open-air public spaces in Taipei seemed not to change significantly during the pandemic. More people spent time on outdoor activities with the belief to stay healthy during the pandemic, as shown in the Google Mobility Report. This suggested a general sentiment of the population in Taipei to consider open-air public space as less risky for COVID-19 transmission, it also attributed to the general trust in the government's recommendations on where and when to wear masks. In addition, because the CDC provided information (anonymously) about confirmed infection cases and the places which infected persons had visited during their I4-days COVID-19 incubation period, people would avoid, if possible, such places until the end of the 14days period (Taiwan News, 2020). Due to the CDC's strategy to close places for a short period of time only after the rare cases of confirmed infections, people's daily activities in public open space did not significantly change in Taipei under COVID-19.

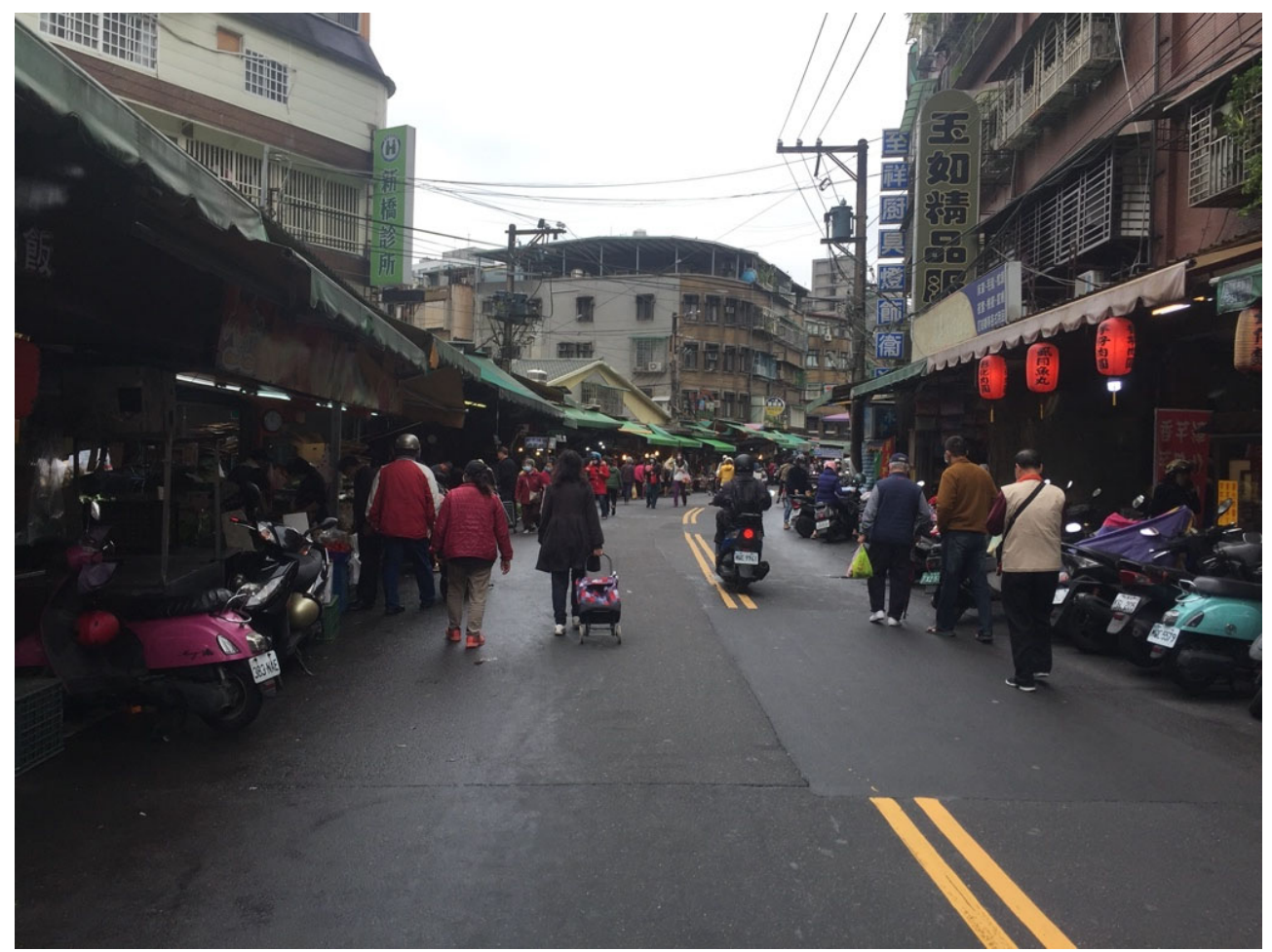

Figure 4. While restaurants remained open in Taipei, many residents bought ingredients in the markets and cooked at home. As smaller streets in the older districts have often no rigid separations between pedestrians and vehicles, people took over the streets, while vehicles adopted (April 2020)

Despite the similar behaviour and usage of public space in Taipei, significant differences can be identified regarding health disparity and access to public space between the cities, particularly affecting vulnerable groups in Hong Kong. Over the last years, Hong Kong's Gini coefficient increased to 53.9 (Central Intelligence Agency, 2016), one of the highest in Asia and indicating severe social inequality. I.3 million of Hong Kong's 7.45 I million inhabitants live in poverty (2018). In contrast, The Gini coefficient reaches only 33.6 (Central Intelligence Agency, 20I4), indicating a far more balanced society of 
Taipei. As mentioned above, in Taipei, all citizens and documented residents are protected by the $\mathrm{NHI}$, guaranteeing access to public and private medical services at highly subsidized rates. Hong Kong has a volunteer health insurance scheme, and all identity card holders are entitled to subsidized services only in public hospitals. During the current health crisis, Hong Kong's vulnerable groups like elderly, lowincome families, subdivided units' residents, homeless, migrant workers, and newly unemployed are more severely affected. Many tried to stay home if possible, to reduce the infection risk, and had no access to masks or reused masks for many days. This, in addition to long working hours, affected their access to public space and country parks (which are normally at the periphery of the city and would incur transportation time and costs as mentioned), which have proven generally to be positively correlated to one's well-being. Moreover, in Hong Kong's highly dense living environment, staying at home could be highly stressful. According to Professor Paul Yip Siu-fai, director of the University of Hong Kong's Centre for Suicide Research and Prevention, "Many people in Hong Kong live in small homes, and the stay-home advice as well as the suspension of public services have entrenched inequality in the city." (Ting, 2020).

The Sunday gatherings of Hong Kong's 400,000 domestic workers in public streets and spaces, parks, promenades as well as footbridges were common scenes in Hong Kong before the pandemic. The "four-people ban", recently limited to two, meant that most of the domestic workers had to stay at "home" on their only day-off. As they generally live with their employers, staying at "home" on their day-off blurred the line between work and rest. Cases had been reported in which domestic workers were not allowed to leave the house on their weekly day-off, forced to continue working, or were asked to resign if they would go out. In fact, according to a survey conducted by Asian Migrants Coordinating Body in March, 2020 with over I, I 27 workers, 20\% were not "given their weekly rest day or got less than what they should get this past month", $25 \%$ who stayed at home on their day-off were asked to work.

Meanwhile in Taipei, the government decided to ban specific large-scale activities in certain public spaces after related cases were confirmed. For example, when a migrant caregiver tested positive for COVID-19 on 26 February (Everington, 2020), the government began banning people's gatherings in the Taipei Main Station Lobby, usually a highly frequented gathering place for migrant workers (Huang, 2020). Such regulations caused citizen protests, and the station lobby was redesigned while the epidemic has been controlled to welcome the public and a wide range of activities.

The restricted opening hours of third spaces such as restaurants and privately-owned public spaces also affected the vulnerable parts of the population in Hong Kong. Some 448 homeless who slept regularly at McDonalds, also known as McRefugees, had to go back onto the streets as the chain had to close their outlets at 6pm for two weeks in late March. The closing of public facilities such as showers at sport centres also affected homeless who had relied on them. (Low, 2020) When the third wave hit and all restaurants had to close temporarily their dining spaces, this group, in addition to bluecollar workers, faced extreme difficulties finding safe spaces to stay and eat respectively. 
Observations on Access and Use of Public Space during COVID-19 in Hong Kong and Taipei

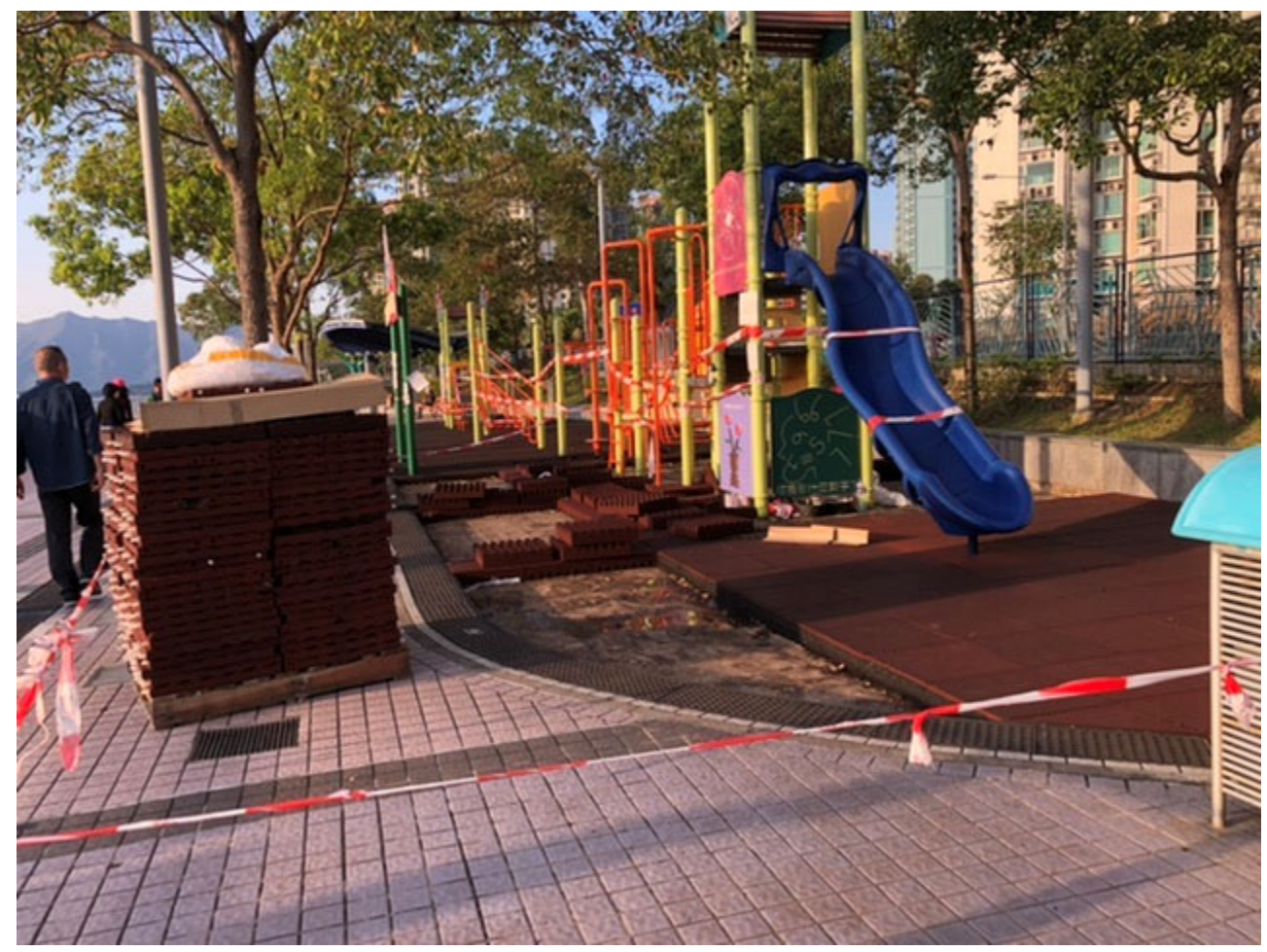

Figure 5. Closed playground at the waterfront in Ma On Shan, Hong Kong (April 2020).

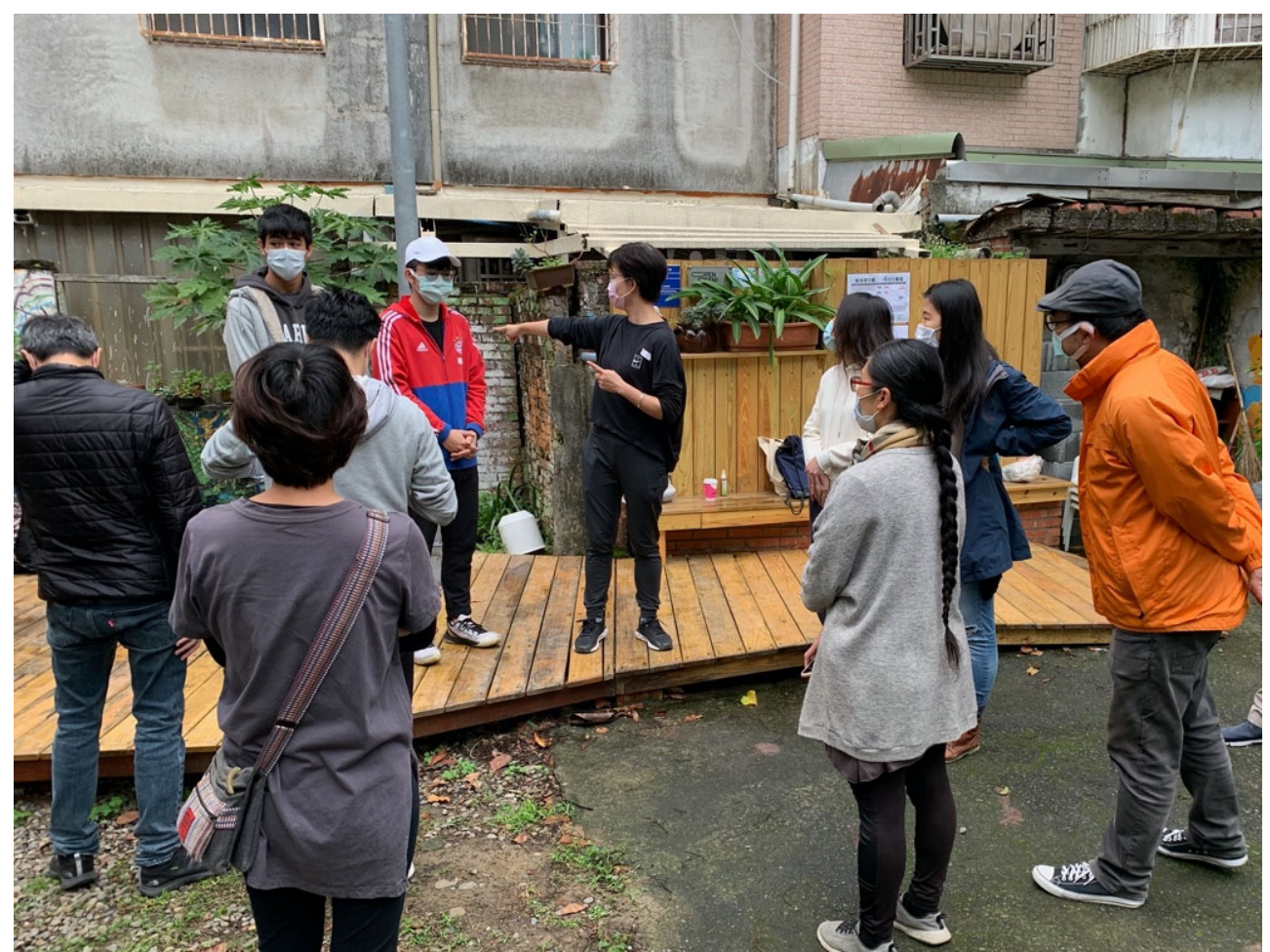

Figure 6. Community gardening events in Taipei continued under the pandemic, however, in early April, due to the second infection wave, participants were asked to wear masks and provide contact details in case of infection cases (photo April 2020). 


\section{Takeaways and Preliminary Considerations for Future Pandemic Preparedness}

Hong Kong and Taipei showed how swift responses by the governments and civil societies helped to avoid de facto lockdowns and community outbreaks, and to keep numbers of infections and deaths low. Their example also demonstrates that high urban density does not necessarily lead to higher infection numbers. Yet, the current pandemic also revealed underlying social challenges, if not well addressed, could undermine cities' pandemic preparedness and resilience. Public space is inevitably constructing crucial parts of urban life for health and recreation purposes. During a pandemic they have two key roles: (I) they may be spaces which incur risks of infection, but (2) they also provide key access to amenities, commercial spaces and jobs, as well as physical exercise and relaxation.

In Hong Kong the link between epidemics and public space goes far back in time, with the first public park Blake Gardens created in 1905 in the aftermath of the bubonic plague (Chu, 20I5). Streets and sidewalks in its hyperdense urban districts are narrow and cramped, and occupied by clutters of economic activities, making it nearly impossible to maintain physical distance. Since the early 2000s there have been initiatives of civic society groups such as Walk DVRC to increase spaces for pedestrians and non-motorized transport. During this pandemic, such initiatives were proposed and partly already implemented in many American and European cities (Koop, 2020; Cabinet Office UK Government, 2020; Bliss, 2020). The experience of COVID-19 would offer a prime opportunity to implement such schemes, especially in Hong Kong's most dense low-income districts. However, such actions are not yet taken.

In Taipei, the significant increase in the use of shared bikes, reduced use in vehicles and public transport systems, and the organic use of the riverside parks might be interpreted as how existing sustainable transportation alternatives and human-centric public space designs helped the population react in the moment of crisis, and therefore improve the city's resilience. This would be a crucial point for post-COVID urban designs, and important to be further investigated.

As in other places, existing socio-spatial problems were further pronounced by the pandemic leading particularly in Hong Kong to precarious conditions, which were not reflected in the low numbers of COVID-19 infections and fatalities. The increasing wealth-gap, evident in the city's staggering high Gini coefficient, increased the pressure to find appropriate housing and open space. Most dramatic is the situation for people living in the city's subdivided units, with no place for physical distancing and mental relief. This paper has been a first comparative study of the usage and policies of public space of both cities during the pandemic, further in-depth studies are planned to follow.

Questions which should be further explored are: (I) What affected most people's access to public spaces during the pandemic? (2) Which were the most problematic spatial conditions and how did they affect different vulnerable groups? (3) What kind of spaces were important to provide relief from mental stress and allow physical activities? (4) And, how could initiatives, such as the widening of sidewalks and closure of vehicular lanes, be implemented to provide more inner-city public spaces for citizens. 


\section{Acknowledgement}

This paper was submitted in July 2020 and thus represents information collected up to this date. The paper is part of a larger ongoing research project of the authors supported by a RGC Development Fund provided by the Chinese University of Hong Kong and a Worldwide Universities Network Fund.

\section{References}

Asian Migrants Coordinating Body (AMCB) (2020) 'Results of Online Survey on the Situation of Migrant Domestic Workers during COVID-19 outbreak'. 16 March [online]. Available at: https://www.facebook.com/groups/amcb.hk/permalink/277600/845845740/ (Accessed: 17 May 2020).

Bliss, Laura (2020) 'Mapping How Cities Are Reclaiming Street Space'. Citylab, 3 April [online]. Available at https://www.citylab.com/transportation/2020/04/coronavirus-city-street-publictransit-bike-lanes-covid-19/609190/ (Accessed: 17 May 2020).

Cabinet Office UK Government. (2020) 'Our plan to rebuild: The UK Government's COVID-19 recovery strategy'. 12 May [online]. Available at: https://www.gov.uk/government/publications/our-plan-to-rebuild-the-uk-governments-covid19-recovery-strategy/our-plan-to-rebuild-the-uk-governments-covid-19-recovery-strategy (Accessed: 17 May 2020).

Central Intelligence Agency. 'The World Factbook'. [online] Available at: https://www.cia.gov/library/publications/the-world-factbook/rankorder/2I72rank.html (Accessed: 17 May 2020).

Centre for Health Protection (2020) 'Latest Situation of Coronavirus Disease (COVID-19) in Hong Kong' [online]. Available at: https://chp-dashboard.geodata.gov.hk/covid-I9/en.html (Accessed: 17 May 2020).

Census and Statistics Department, HKSAR (2018) 'Thematic Report: Persons Living in Subdivided Units' [online]. Available at: https://www.statistics.gov.hk/pub/BII201022016XXXXB0100.pdf (Accessed: 17 May 2020).

Census and Statistics Department, HKSAR (2020) 'Table E489: Land area, mid-year population and population density by District Council district' II March, [online]. Available at: https://www.censtatd.gov.hk/hkstat/sub/spl50.jsp?.productCode=D5320I89 (Accessed: 17 May 2020).

Chen, Wei-ting \& Hau, Elizabeth (2020) 'Taiwan's Ban on Mask Exports to be Extended until the end of June'. Focus Taiwan CNA English News, I 3 April [online]. Available at: https://focustaiwan.tw/society/202004I300I7 (Accessed: 17 May 2020).

Chu, Judy (20I5) 'HKG/ Legacy of Plague I: Blake Garden'. Faculty of Architecture, The University of Hong Kong, 16 December [online]. Available at: https://fac.arch.hku.hk/asian-cities-research/hkglegacy-of-plague-i-blake-garden/ (Accessed: 17 May 2020).

Everington, Keoni (2020) 'Indonesian Infected with Coronavirus Traveled Extensively on Taipei MRT, TRA'. Taiwan News, 27 February [online]. Available at: https://www.taiwannews.com.tw/en/news/3882260 (Accessed: 17 May 2020).

Google (2020a) 'COVID-I 9 Community Mobility Report, Hong Kong'. 2 I Julyl [online]. Available at: https://www.gstatic.com/covid I9/mobility/2020-04-17 HK_Mobility Report_en.pdf (Accessed: 28 July 2020).

Google (2020b) 'COVID-19 Community Mobility Report, Taiwan. 2I July [online]. Available at: https://www.gstatic.com/covid 19/mobility/2020-04-17_TW_Mobility_Report_en.pdf (Accessed: 28 July 2020).

Ho, Kelly (2020) 'Coronavirus: Hong Kong Gov't Reveals Producers of Giveaway Masks, as Applicants Raise Privacy Concerns'. Hong Kong Free Press, 7 May [online]. Available at: 
https://hongkongfp.com/2020/05/07/coronavirus-hong-kong-govt-reveals-producers-ofgiveaway-masks-as-applicants-raise-privacy-concerns/ (Accessed: 17 May 2020).

Huang, Tzu-ti (2020) 'Sitting on Floor of Taipei Main Station Lobby Banned due to Coronavirus'. Taiwan News, 29 February [online]. Available at: https://www.taiwannews.com.tw/en/news/3883174 (Accessed: 17 May 2020).

Koop, Fermin (2020) 'After Lockdown, Milan Wants to Transform the Way People Move Around the City' 2I April [online]. Available at: https://www.zmescience.com/science/milan-afterlockdown-movement-citizens-922352/ (Accessed: 17 My 2020).

Lai, Carine (2017) 'Unopened Space: Mapping Equitable Availability of Open Space in Hong Kong' Hong Kong: Civic Exchange [Report]. Available at: http://civic-exchange.org/report/unopenedspace-mapping-equitable-availability-of-open-space-in-hong-kong/ (accessed I7 July 20I8).

Lam, Jeffie, and Sum, Lok-kei and Ng, Kang-chung (2019) 'Hong Kong Elections: Pro-Democracy Camp Wins 17 Out of 18 Districts While City Leader Says She Will Reflect on the Result.' South China Morning Post, 25 November [online]. Available at: https://www.scmp.com/news/hong-kong/politics/article/3039151/hong-kong-elections-tsunamidisaffection-washes-over-city (Accessed: 18 May 2020).

Low, Zoe (2020) 'Coronavirus: Lockdown of Public Showers Leaves Hong Kong's Homeless Struggling to Stay Clean Amid Covid-1 9 Pandemic'. South China Morning Post, I 8 March [online]. Available at: http://scmp.com/news/hong-kong/society/article/30756/4/coronavirus-lockdownpublic-showers-leaves-hong-kongs (Accessed: 17 May 2020).

Low, Zoe and Chan, Ho-him (2020) 'Coronavirus: Hong Kong's homeless 'McRefugees' Scramble for Places to Stay as McDonald's Axes Dine-In Services in Evening to Help Fight Pandemic'. South China Morning Post, 25 March [online]. Available at: https://www.scmp.com/news/hongkong/health-environment/article/3076804/coronavirus-hong-kongs-homeless-mcrefugees (Accessed: 17 May 2020).

Ng, Naomi (2018) 'Hong Kong's Small Flats “To Get Even Smaller”, Hitting Quality of Life'. South China Morning Post, 17 April [online]. Available at: https://www.scmp.com/news/hongkong/economy/article/2142165/hong-kongs-small-flats-get-even-smaller-hitting-quality-life (Accessed: 17 May 2020).

National Health Insurance Administration (2020) ‘Name-Based Mask Distribution System’. 7 April [online]. Available at:

https://www.nhi.gov.tw/english/Content_List.aspx?n=022B9D97EF66C076 (Accessed: 17 May 2020).

Public Works Department, Taipei City Government (2019) 'Statistics'. 30 August [online]. Available at: https://english.pwd.gov.taipei/cp.aspx?n=A2DC33C92E50FDBD\&s=B3BED3C3BCIE09I0 (Accessed: 17 May 2020).

Rizzo, Meredith and Hersher, Rebecca. (2020) 'It's Not Easy For Anyone: Coronavirus Disrupts Life And Work In Hong Kong.' NPR News, I 3 February [online]. Available at: https://www.npr.org/sections/goatsandsoda/2020/02/I3/8055I I 970/it-s-not-easy-for-anyonecoronavirus-disrupts-life-and-work-in-hong-kong (Accessed: 18 May 2020).

Shan, Shelley (2020) 'Virus Outbreak: Dajia Matsu Pilgrimage is postponed.' Taipei Times, 28 February [online]. Available at: https://www.taipeitimes.com/News/front/archives/2020/02/28/2003731748 (Accessed: 17 May 2020).

Shiroma Silvia (2020) 'Coronavirus: How map hacks and buttocks helped Taiwan fight Covid-19'. BBC News, 7 June [online]. Available at: https://www.bbc.com/news/technology-52883838 (Accessed: 8 March 2021).

Strong, Mathew (2020) 'Wearing a Face Mask to Become Compulsory on the Taipei MRT from April 4'. Taiwan News, 3 April [online]. Available at: https://www.taiwannews.com.tw/en/news/390970I (Accessed: 17 May 2020). 
Taipei City Government (2017) 'Demographic Overview'. I3 December [online] Available at: https://english.gov.taipei/cp.aspx?n=C619997124A6D293 (Accessed: 17 May 2020).

Taiwan Centers for Disease Control (2014) 'SARS (Severe Acute Respiratory Syndrome)' 24 November [online]. Available at: https://www.cdc.gov.tw/En/Category/ListContent/bg0g_VU_Ysrgkes_KRUDgQ?uaid=uID6dR GtmP4Q5YAIGmSKIw (Accessed: 17 May 2020).

Taiwan Centers for Disease Control (2018) 'NHCC: Origin'. 31 January [online]. Available at: https://www.cdc.gov.tw/En/Category/MPage/gL7-bARtHyNdrDq882p/9Q (Accessed: 17 May 2020).

Taiwan Centers for Disease Control (2020a) 'COVID-19 (SARS-CoV-2 Infection)' [online]. Available at: https://sites.google.com/cdc.gov.tw/2019-ncov/taiwan?authuser=0 (Accessed: 17 May 2020).

Taiwan Centers for Disease Control (2020b) 'Name-Based Rationing System for Purchases of Masks to be Launched on February 6; Public to Buy Masks with Their NHI Cards'. 4 February [online]. Available at:

https://www.cdc.gov.tw/En/Bulletin/Detail/ZlJrlunqRjM49LIBn8p6eA?typeid=I58 (Accessed: 17 May 2020).

Taiwan News (2020) 'Taipei, New Taipei, and Keelung Cleared of Coronavirus Risks'. Taiwan News, 14 February [online]. Available at: https://www.taiwannews.com.tw/en/news/3876227 (Accessed: 17 May 2020).

The Reporter (2020) 【不斷更新】武漢肺炎大事記：從全球到台灣, 疫情如何發展？ [online]. Available at: https://www.twreporter.org/a/2019-ncov-epidemic (Accessed: 17 May 2020).

Ting, Victor (2020) 'Coronavirus: Suicide Experts Warn of Pandemic's Impact on Mental Health, with Hong Kong's Jobless, Poor and Elderly Most at Risk'. South China Morning Post, 26 April [online]. Available at: https://www.scmp.com/news/hong-kong/healthenvironment/article/3081582/coronavirus-suicide-experts-warn-pandemics-impact (Accessed: 17 May 2020).

World Health Organization (2020) 'WHO Coronavirus Disease (COVID-I9) Dashboard' [online]. Available at: https://covid I9.who.int/ (Accessed: 17 May 2020).

Yau, Yat-Man (200I) 'The Study of the Process of Water Development and the Land Use Along the Riverside of Taipei Areas [大台北地區水利開發的歷程與河岸地利用的研究]' Geographical Research [師大地理研究報告], 35.

YouBike Co. (2020) 'What is YouBike' [online]. Available at: https://taipei.youbike.com.tw/about/youbike?5cc296a4083e7b59672d2d52 (Accessed: 17 May 2020).

Zhang, Karen (2020) 'Coronavirus: Free Masks from Hong Kong Government Appear for Sale Online'. South China Morning Post, 12 May [online]. Available at: https://www.scmp.com/news/hong-kong/health-environment/article/3084076/coronavirus-freemasks-hong-kong-government (Accessed: 17 May 2020).

Tsai Ya-hua [蔡雅樺] (2020) 疫情帶動YouBike、共享運具使用增加。Liberty Times Net, 24 April [online]. Available at: https://news.Itn.com.tw/news/life/paper/1365632 (Accessed: 17 May 2020).

Zheng Wei [鄭煒] (2020) 民調：近七成民眾 力挺購買口罩實名制。《經濟日報》，II February [online]. Available at: https://money.udn.com/money/story/5658/4337455 (Accessed: 17 May 2020).

Zheng Ming [鄭銘] (2020) 世衛贊香港防疫 何栢良：是港人自救防疫。Sound of Hope, 5 March [online]. Available at: https://www.soundofhope.org/post/350722?lang=b5 (Accessed: 17 May 2020).

I 04 | The Journal of Public Space, 5(3), 2020 | ISSN 2206-9658

City Space Architecture / UN-Habitat 